\title{
THE ROLE OF BUD BANK IN GLYPHOSATE TOLERANCE OF TWO HERBACEOUS SPECIES
}

\author{
El ROL DEL BANCO DE YeMAS EN LA TOLERANCIA A GLIFOSATO DE dOS \\ ESPECIES HERBÁCEAS
}

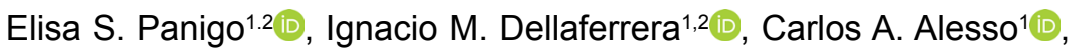 \\ Abelardo C.Vegetti ${ }^{1,2}$ and Mariel G. Perreta ${ }^{1,2}$ (-)
}

\begin{abstract}
1. Universidad Nacional del Litoral, Facultad de Ciencias Agrarias, Pbro Kreder 2805. S3080HOF Esperanza, Santa Fe, Argentina.

2. Consejo Nacional de Investigaciones Científicas y Técnicas (CONICET).

*epanigo@fca.unl.edu.ar
\end{abstract}

Citar este artículo PANIGO, E. S., I. M. DELLAFERRERA, C. A. ALESSO, A. C.VEGETTI \& M. G. PERRETA. 2019. The role of bud bank in glyphosate tolerance of two herbaceous species. Bol. Soc. Argent. Bot. 54: 553-565.

DOI: http://dx.doi. org/10.31055/1851.2372.v54. n4.24301

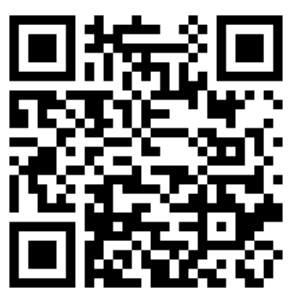

Recibido: 13 Mayo 2019 Aceptado: 10 Octubre 2019 Publicado: 15 Diciembre 2019 Editor: Ramiro Aguilar

ISSN versión impresa 0373-580X ISSN versión on-line 1851-2372

\section{SUMMARY}

Background and aims: Commelina erecta and Eutsachys retusa are two perennial weeds, which show high resprouting after glyphosate application. This behavior represents a serious problem for weed management. The purpose of this study was to characterize the bud bank of both species and to assess their response to glyphosate application.

M\&M: We analyzed 120 reproductive shoots of $C$. erecta, and 60 reproductive shoots of $E$. retusa, at 30- and 60-days post- herbicide application. The doses applied to $C$. erecta were 0 (control), 1.200 and $2.400 \mathrm{~g}_{\text {a.i. ha }}{ }^{-1}$, and to $E$. retusa were 0 (control), 480 and $1200 \mathrm{~g}$ a.i. ha ${ }^{-1}$.

Results: We found that both species presented active buds in approximately $50 \%$ of their nodes, even after herbicide application. Bud bank dynamics changed in both weeds after herbicide application, and therefore their growth pattern. The activation of originally inhibited buds allowed weeds to regrow and survive after glyphosate application altering their architecture.

Conclusions: The bud bank plays an important role in glyphosate tolerance in both weeds. The resprouting capacity in both species was similar for any dose of glyphosate applied. Therefore, an alternative control strategy based on the increase of the dose of herbicide would not be a successful alternative for the management of these weeds. The interruption of the storage of reserves in the rhizome system and the reduction of the number of buds would be key to effective long-term management of these and other perennial weeds in no tillage cropping system.

\section{KEY WORDS}

Commelina erecta, Eustachys retusa, herbicide, regeneration, weeds.

\section{RESUMEN}

Introducción y objetivos: Commelina erecta y Eutsachys retusa son malezas perennes tolerantes a glifosato. El propósito de este estudio fue caracterizar el banco de yemas de ambas especies y evaluar su respuesta a la aplicación de glifosato.

M\&M: Se analizaron yemas de 120 ejes reproductivos de C. erecta y 60 ejes reproductivos de $E$. retusa, a los 30 y 60 días después de la aplicación del herbicida. Las dosis empleadas en $C$. erecta fueron 0 (control), 1.200 y $2.400 \mathrm{~g}$ a.i. ha-1 y en $E$. retusa fueron 0 (control), 480 y $1200 \mathrm{~g}$ a.i. ha $^{-1}$.

Resultados: Ambas especies presentaron yemas activas en aproximadamente el $50 \%$ de los nudos, incluso después de la aplicación del herbicida. Ambas malezas alteraron la dinámica del banco de yemas y su patrón de crecimiento post-aplicación del herbicida. Es decir, la activación de yemas originalmente inhibidas permitió que ambas malezas rebroten y sobrevivan, alterando su arquitectura.

Conclusiones: El banco de yemas juega un papel importante en la tolerancia a Glifosato en ambas malezas. En ambas especies, la capacidad de rebrote fue similar en cualquiera de las dosis de glifosato aplicadas; por lo tanto, una estrategia de control que aumente la dosis de herbicida no sería una alternativa exitosa para el manejo de estas malezas. La interrupción del almacenamiento de reservas en el sistema de rizomas y la reducción de la cantidad de yemas, serían factores claves para un manejo efectivo a largo plazo de estas y otras malezas perennes, en un sistema de labranza cero.

\section{Palabras Clave}

Commelina erecta, Eustachys retusa, herbicida, malezas, regeneración. 


\section{INTRODUCTION}

The term bud bank was defined in plant species by Harper (1977). Klimešová \& Klimeš (2007) formulated some principles that unified the concept, defining it as the meristem system present in plants for annual renewal or regeneration of new branches following a disturbance (Harper, 1977; Klimešová $\&$ Klimeš, 2007). The role of the bud bank has been recognized as an adaptive response to disturbances in numerous ecosystems (Bond \& Midgley, 2001; Deng et al., 2013). In agroecosystems, this role has been mainly related to grazing (Busso et al., 1989, 2011; Hendrickson \& Briske, 1997). However, after herbicide application and destruction of most of its above-ground biomass, certain perennials species can resprout (Malpassi, 2005; Panigo et al., 2012, 2016; Dellaferrera et al., 2015). Plants have two strategies to deal with severe agricultural disturbance: shortening their life cycle and surviving disturbance events as seeds (avoidance), or by means of underground bud banks with large regeneration capacity (tolerance) (Klimešová et al., 2008). A successful regeneration via the bud bank is key to population persistence (Ott \& Hartnett, 2015). Hence, knowledge on bud bank traits is essential to optimize weed management practices.

Resprouting is a strategy of individual plants to persist in situ after disturbances (natural or anthropogenic), therefore it is a key functional trait indicator of the persistence niche of the plant species (Bond \& Midgley, 2001). Resprouting capacity can be estimated indirectly in the field or ex situ, based on bud traits assessment. For example, the indirect assessment of the resprouting capacity can be easily done by counting the vegetative buds and analyzing their viability (Klimešová \& Klimeš 2007). The buds can exhibit different size during the vegetative phase at different positions along the stem (Waldie et al., 2010). Although large preformed buds represent a relatively large initial investment both in construction and maintenance, they have a relatively low cost for, as well as a rapid response to, activation (Vesk \& Westoby, 2004). The analysis of the distribution of buds along the vertical axis of the plant could give an idea of how the plant may respond to disturbance, as well as the circumstances under which this ability could be used. For example, plants with high resprouting capacity are characterized by having more stems per plant, greater basal shoot area, shorter potential height and deeper buds than weak resprouters (Vesk et al., 2004).
Commelina erecta L. (Dayflower) and Eustachys retusa (Lag.) Kunth (Argentine fingergrass) are plant species native to South America and frequently reported as species with low sensitivity to glyphosate (Puricelli \& Faccini, 2005; Dellaferrera et al., 2007; Nisensohn et al., 2011; Panigo et al., 2012, 2016). In previous morphological studies, we found that both species survive after glyphosate applications thanks to their ability to recover foliar mass through the regrowth of buds that are not developed under normal conditions (Panigo et al., 2012, 2016). Therefore, the application of glyphosate to C. erecta and $E$. retusa would not affect their bud bank and consequently their ability to resprout. The behavior of the bud bank of these species is unknown, for this reason our objectives were: i) to characterize the bud bank of these two species; ii) to evaluate the effect of glyphosate application on the buds; and iii) to analyze the implication in the development of management strategies. Knowledge of the dynamics (location, quantity and quality) of the bud bank and its response to herbicide applications would provide a more accurate information to predict regrowth patterns and find appropriate management strategies.

\section{MATERIALS AND METHODS}

\section{Background}

Commelina erecta (Commelinaceae) and Eustachys retusa (Poaceae) were studied because we identified, through architectural analysis, combinations of morphological features that facilitate regrowth after herbicide applications (Panigo et al., 2012, 2016). Commelina erecta is a perennial herb, with adventitious roots and a rhizome system (Panigo \& Nisensohn, 2018). Eustachys retusa is a perennial grass $(\mathrm{C} 4)$, cespitose with short rhizomes and compressed tillers (Burkart, 1969).

\section{Plant material and growth condition}

Plants and seeds for this research were collected in the city of Esperanza ( $\left.-31^{\circ} 26^{\prime} \mathrm{S}-60^{\circ} 55^{\prime} \mathrm{W}\right)$, Santa $\mathrm{Fe}$ province, Argentina, at urban areas with no records of herbicide applications. Two types of shoots were evaluated in C. erecta: (1) plumular axes, coming from seedlings and (2) vegetative cloning axes (VCA), coming from the regeneration of axillary fragments of rhizomes with 2 buds, therefore of second or higher order of branching. In E. retusa, only 


\section{E. S. Panigo et al. - Bud bank in herbaceous species}

basal axillary shoots (or axes) of second or greater order of branching of plants raised from seeds were evaluated. In both species, each axis was considered as individual experimental units.

The VCAs and seedlings of $C$. erecta were transplanted to $1 \mathrm{~L}$ plastic pots and placed in a growth chamber, following the conditions used by Panigo et al. (2012). For E. retusa, seedlings were transplanted to $5 \mathrm{~L}$ plastic pots. E. retusa did not tolerate the radiation conditions of the growth chamber, thus the trials were performed in a greenhouse under natural radiation conditions. The orientation of the greenhouse was SE-NW. The average maximum and minimum temperatures inside the greenhouse in spring and summer during the trial were 29-15 and $32-19{ }^{\circ} \mathrm{C}$, respectively. All plants were irrigated with demineralized water in order to keep them under suitable water conditions.

\section{Herbicide treatments}

Glyphosate [Estrella, glyphosate as the isopropylamine salt at $480 \mathrm{~g} \mathrm{~L}^{-1}(48 \% \mathrm{w} / \mathrm{v})$ (ACA)] was applied on day 0 of the experiment, with an experimental spray chamber using a flat fan nozzle (FE80/0.8/3) calibrated to deliver 200 $\mathrm{L} \mathrm{ha}^{-1}$ at a pressure of $275 \mathrm{kPa}$. The selection of doses was based both on the recommendations of Phytosanitary Products Guide for Argentina (CASAFE, 2007) and on previous studies (Panigo et al., 2012, 2016). For each species, the herbicide treatments included two doses of glyphosate and an untreated control. The doses of glyphosate applied to $C$. erecta were: 1200 and 2400 grams of active ingredient per hectare $\left(\mathrm{g}\right.$ a.i. ha $\left.{ }^{-1}\right)$. The treatments in $C$. erecta were applied to plants in vegetative stage, with six or seven leaves in the main stem. It is well known that plants with less than 5 leaves are sensitive to glyphosate (Rainero, 2004). The doses applied to E. retusa were 480 and $1200 \mathrm{~g}$ a.i. ha ${ }^{-1}$. The herbicide treatments in E. retusa were applied after the meristem of the embryonic axes has ceased growth (by flowering). E. retusa is glyphosate tolerant at reproductive stage (Puricelli \& Faccini, 2005).

\section{Procedure}

One hundred and twenty axes of $C$. erecta (between VCA and plumulars) and 60 axes of $E$. retusa were evaluated in two sampling dates, at 30 and 60 Days After the Herbicide Application
(DAHA). Ten axes per treatment were employed (origin $\mathrm{x}$ dose $\mathrm{x}$ time). Each axis was selected and drawn from an individual pot. Reproductive axes were used to ensure that axillary bud differentiation and maturation had ceased. For each axis selected shape, size, number and viability of the buds were assessed. Bud size and number were evaluated in relation to the architecture of each species. For this purpose, the nodes per axes were divided into three groups based on their position along the principal axis. These groups or zones were designated as apical, mid, and basal according to previous studies (Panigo et al., 2012, 2016).

In both species, the nodes of each axis were counted and classified according to their position and the presence or absence of buds. For this, buds which had grown out (tiller or branch), bud scars, or absent buds were grouped together as simply "no buds", and the axillary meristems which are enclosed in the prophyll, as "buds". Based on these data, the regrowth capacity was indirectly analyzed comparing the proportion of buds (vs no bud) in each treatment. Then the buds were dissected from the axes and their position on the axis, morphology and size (length from the prophyll apex to the stem insertion point) were recorded. Finally, bud viability was determined by a procedure that includes double staining with 2, 3, 5 Triphenyl tetrazolium chloride (TTC) and Evan's blue, described by Busso et al. (1989). Buds were divided into three viability classes, according to their reaction to TTC staining: active (stained with TTC only), dead or nonviable (stained with Evan's blue solution only), and dormant (not stained neither TTC nor Evans Blue solution). Finally, the regeneration success was analyzed holistically; the number of buds was evaluated in relation to architecture of each species.

\section{Statistical analysis}

Four response variables (size, proportion, viability and number of buds) were modeled in both species as a complete randomized design using a factorial treatment structure model. The statistical procedures varied according to the species and the probability distribution associated with each response variable (Table 1). Data from each species were analyzed separately due to differences in the growth pattern and factors included in the model. All the statistical analysis was carried out using the R software (R Core Team, 2014). 
Table 1. Description of the statistical procedure, factors and sample size used in the species, for each

response variables. Abbreviations: ANOVA: Analysis of Variance, DAHA: days after the herbicide

application, GLS: Generalized Least Squares. GLMM: Generalized Linear Mixed-Model, LSD: Fisher's

LSD post-hoc test.

\begin{tabular}{|c|c|c|c|c|}
\hline $\begin{array}{c}\text { Response } \\
\text { variable }\end{array}$ & Species & Factors & Statistical procedure & Sample size $(n)$ \\
\hline \multirow{2}{*}{$\begin{array}{l}\text { Size and number } \\
\text { (Architectural traits) }\end{array}$} & C. erecta & Dose, origin, zone & GLS + ANOVA LSD & $\begin{array}{l}241 \text { buds at } 30 \text { DAHA and } 216 \\
\text { buds at } 60 \text { DAHA }\end{array}$ \\
\hline & E. retusa & Dose, zone & GLS + ANOVA LSD & $\begin{array}{l}271 \text { buds at } 30 \text { DAHA and } 320 \\
\text { buds at } 60 \text { DAHA }\end{array}$ \\
\hline \multirow[t]{2}{*}{ Proportion of buds } & C. erecta & Dose, origin, date & GLMM + Deviance + contrasts & $\begin{array}{l}10 \text { axes for dose, origin and } \\
\text { date }\end{array}$ \\
\hline & E. retusa & Dose, date & GLMM + Deviance + contrasts & 10 axes for dose and date \\
\hline \multirow{4}{*}{ Viability } & \multirow{2}{*}{ C. erecta } & Dose, origin, date & GLMM + Deviance + contrasts & $\begin{array}{l}287 \text { buds at } 30 \text { DAHA and } 203 \\
\text { buds at } 60 \text { DAHA }\end{array}$ \\
\hline & & $\begin{array}{l}\text { Dose, Viability class, } \\
\text { origin }\end{array}$ & Chi-square test & $\begin{array}{l}287 \text { buds at 30DAHA and } 203 \\
\text { buds at } 60 \text { DAHA }\end{array}$ \\
\hline & \multirow{2}{*}{ E. retusa } & Dose, origin, date & GLMM + Deviance + contrasts & $\begin{array}{l}275 \text { buds at } 30 \text { DAHA and } 318 \\
\text { buds at } 60 \text { DAHA }\end{array}$ \\
\hline & & Dose, Viability class & Chi-square test & $\begin{array}{l}275 \text { buds at } 30 \text { DAHA and } 318 \\
\text { buds at } 60 \text { DAHA }\end{array}$ \\
\hline
\end{tabular}

We assessed how the size and number of buds along the axis responded to glyphosate dose and zone. In the case of $C$. erecta, the origin of the axis was also included as a main factor. Model was fitted using the generalized least squares procedure and significance of effects was assessed by analysis of variance (ANOVA). The differences between treatment means were tested with the multiple comparisons Fisher's LSD post-hoc test at a significance level of $5 \%$.

The proportion of buds and bud viability proportion over time were modeled by fitting a generalized linear mixed-model (GLMM) for repeated measures assuming a Binomial distribution of the errors with logit link function. Factors included in the model were dose and date in both species, and origin for $C$. erecta only. The main effects and interactions of the fixed factors were assessed through analysis of deviance. Specific contrasts were tested using the multcomp package (Hothorn et al., 2008) applying Bonferroni multiple comparison procedure for $\mathrm{p}$ values adjustments at a family-wise significance level of 5\%.

In E. retusa, differences between the proportions of viability classes (active, dead or latent), at each dose of herbicide applied were analyzed using the Chi-square test on each sampling date. In C. erecta, as there are three factors of classification (dose, viability class and origin), differences was analyzed using the Cochran-Mantel-Haenszel test.

\section{Results}

\section{Form and size}

In $C$. erecta, the bud form was similar in all axes tested. Bud shape was triangular, with curved apex and base, being the ones in the basal zone (zone of rhizomes) more conical than the ones in the rest. The prophyll was thin and surrounded the whole bud, changing its color from translucent white to green or brown, according to the bud age; being transparent when immature. These characteristics did not change after herbicide application. As for bud size, significant interaction between origin, dose and zone was detected in both dates $(p=0.0001)$. That is, no constant pattern of variation along all axes and treatment, in bud size was detected in this species. As can be observed in Fig. 1A-D, mean values of size are different between the control and the treated axes, and also between dates for the same level of dose and origin. In general, the buds of higher speed of regrowth were located mostly at the axes from basal and/or mid zones. Only for VCA treated with $1200 \mathrm{~g}$ a.i. ha $\mathrm{h}^{-1}$ at 30 DAHA and VCA control at 60 DAHA, the buds of higher size were located in the 


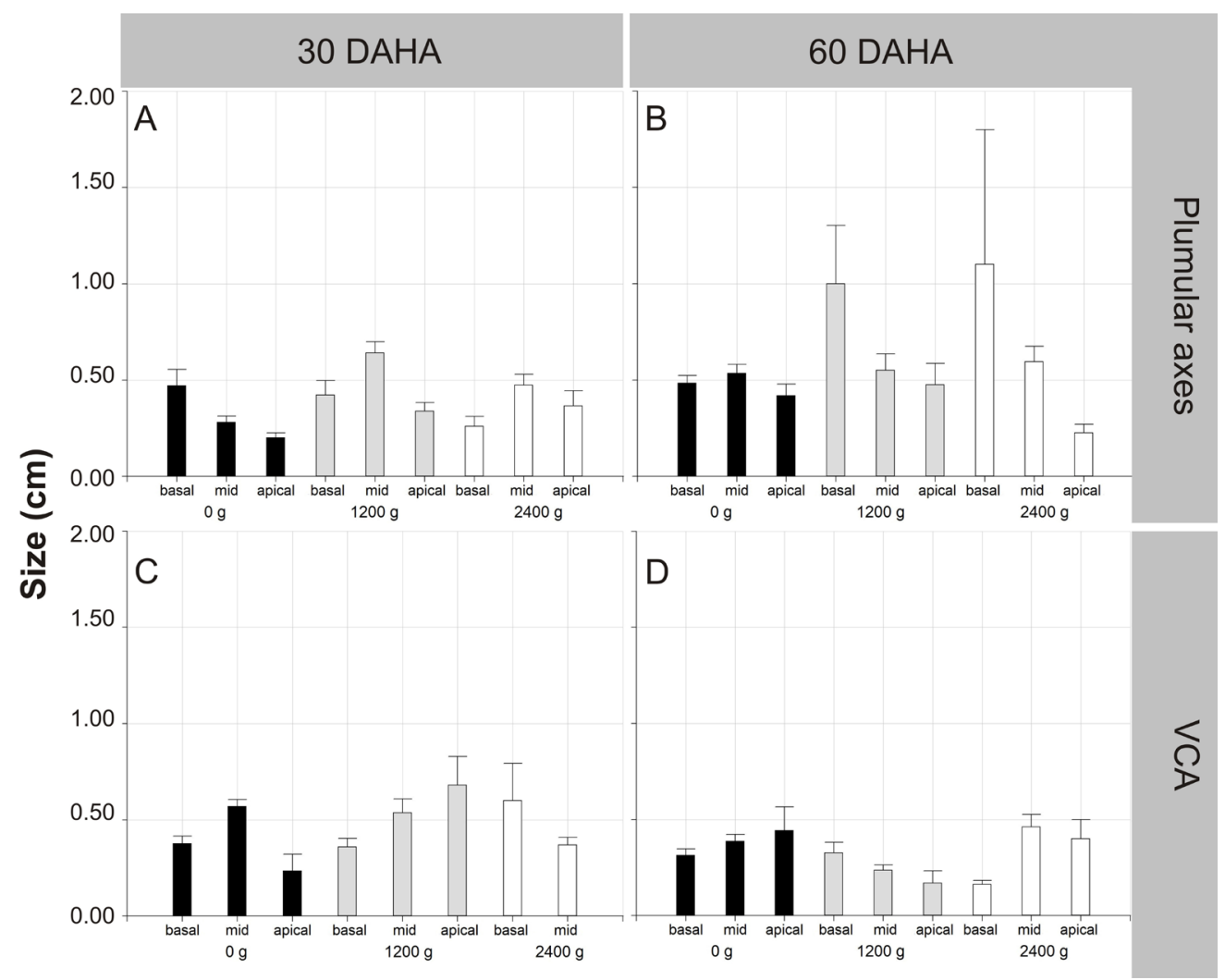

Fig. 1. Bud size along the axis structural areas (basal, mid and apical), in C. erecta. A: Plumular axes at 30 DAHA and B: at 60 DAHA. C: Vegetative cloning axes at 30 DAHA and D: at 60 DAHA. Abbreviations: DAHA: days after the herbicide application, g: $g$ a.i. ha-1, VCA: Vegetative cloning axes. Each color corresponds to an herbicide dose. Values are means \pm standard errors.

apical zone (Fig. 1C- D). The VCA treated with 2400 g a.i. ha ${ }^{-1}$ did not present buds in the apical zone at 30 DAHA in this experiment.

The axillary buds of E. retusa were triangularelongated and slightly rounded. Its prophyll was hardened and the bud color varied with age between light green, yellowish and brown (from young to old). The described morphology was not modified post-glyphosate application. Only in the treated axes with a great part of the aero necrotic biomass, there was high number of buds with dark tones, which were not necessarily dead. A large majority of the buds were relatively long in E. retusa (Fig. 2A-B). The relationship between bud size, zone and herbicide dose was unclear. At 30 DAHA, a significant interaction between factors was found $(\mathrm{p}$ $<0.0001$ ). The bud size depended on the axis zone and herbicide dose. In axes treated with $480 \mathrm{~g}$ a.i. $\mathrm{ha}^{-1}$ the highest regrowth speed was found at the mid zone. Whereas in those treated with $1200 \mathrm{~g}$ a.i. $\mathrm{ha}^{-1}$ the highest regrowth speed was found at the basal zone. At 60 DAHA, only significant differences between zones were found. The middle zone had the maximum bud sizes, in all treatments (Fig. 2B).

\section{Proportion of buds}

In $C$. erecta, most axes maintained buds at around $50 \%$ of nodes, throughout the trial (Fig. 3A- B). The interaction between herbicide dose and sampling date was highly significant, meaning that the effects of the herbicide dose on the bud proportion differed between both dates $(p=0.0095)$. At 30 DAHA, axes treated with the lower dose showed a significantly higher bud proportion compared to those treated with the higher dose $(p=0.032)$, regardless the origin. Untreated plants had intermediate values. At 60 
Bol. Soc. Argent. Bot. 54 (4) 2019

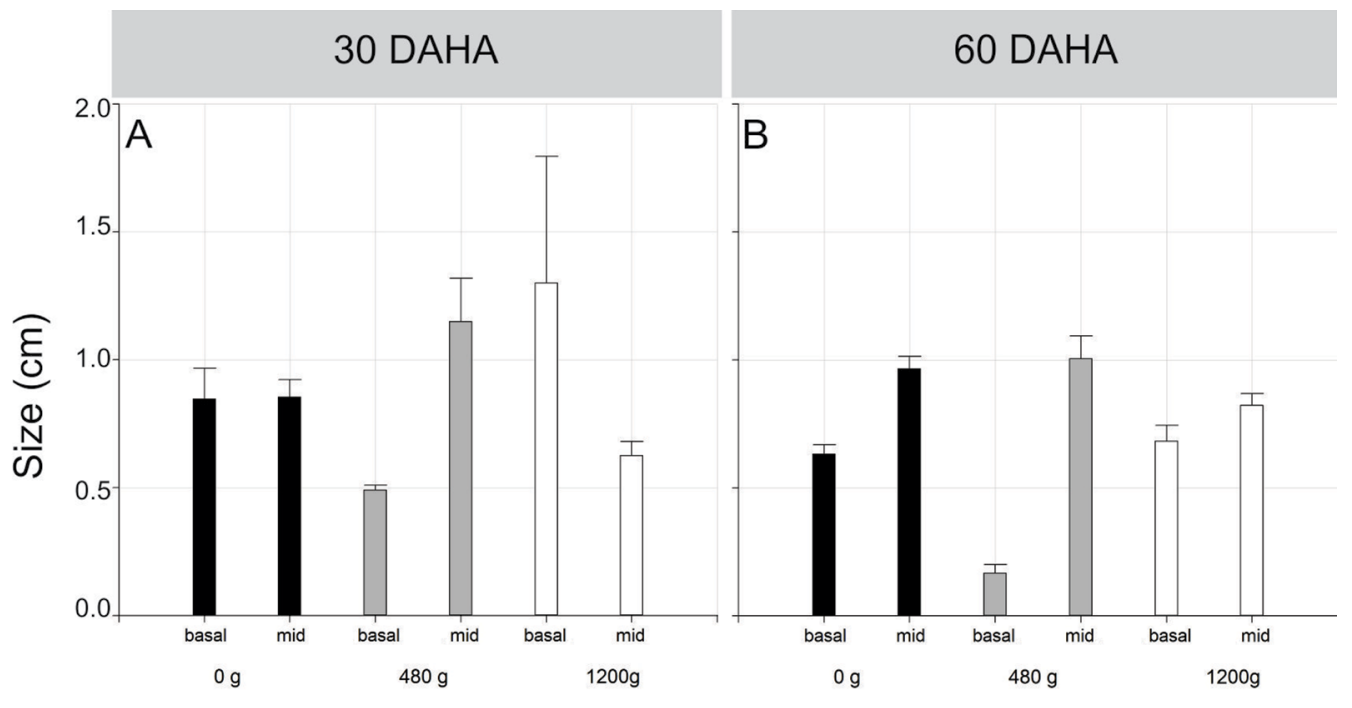

Fig. 2. Bud size along the structural areas (basal, mid and apical) in E. retusa. A: at 30 DAHA and B: at 60 DAHA. Abbreviations: DAHA: days after the herbicide application, g: $g$ a.i. ha- ${ }^{-1}$. Each color corresponds to an herbicidal dose. Values are means \pm standard errors.

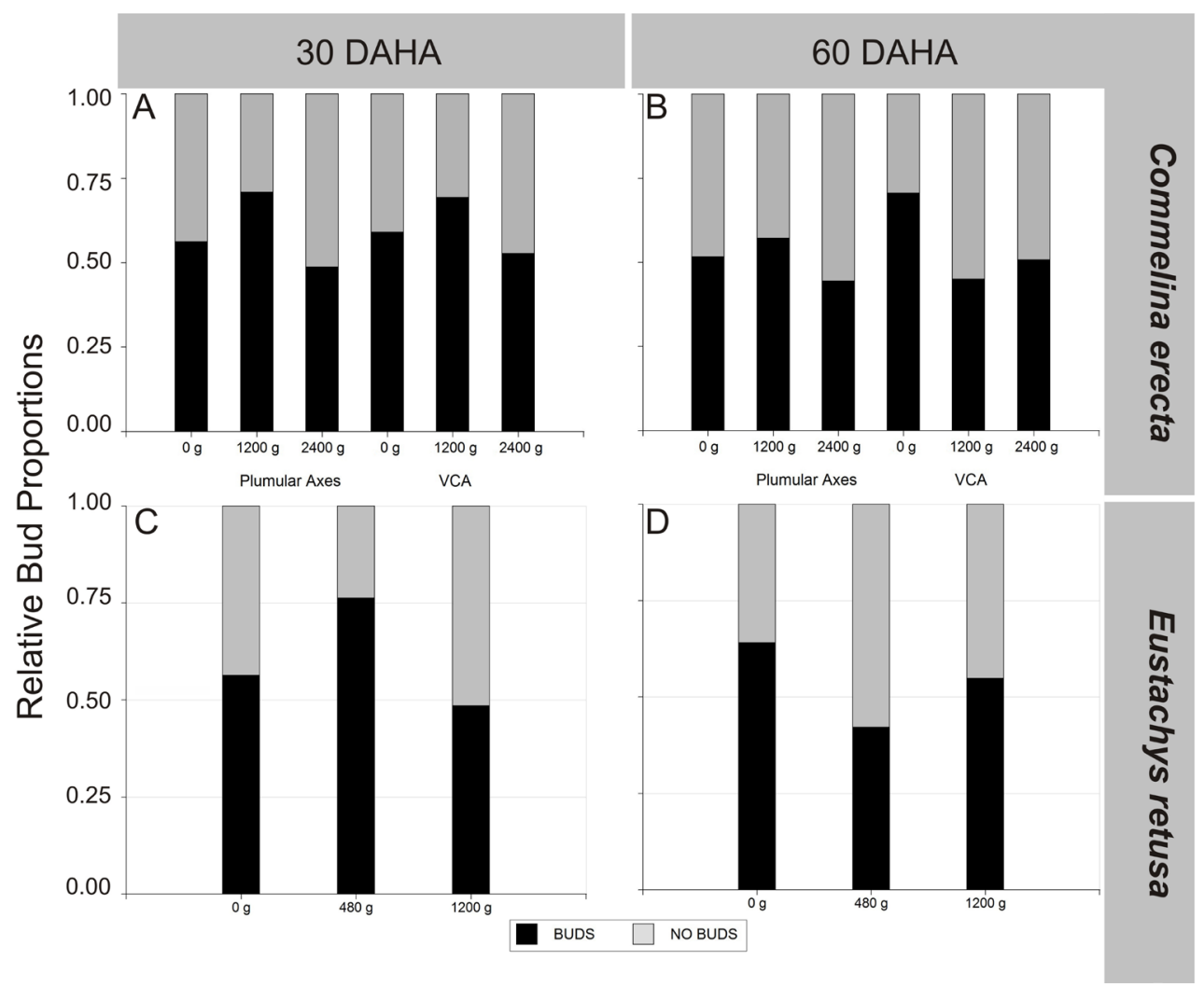

Fig. 3. Proportion of meristems that remain as buds vs. the ones that do not (grown out, scars or absent), in both species. A: C. erecta, at 30 and B: C. erecta, at 60 DAHA. C: E. retusa, at 30 and D: E. retusa, at 60 DAHA. Abbreviations: DAHA: days after the herbicide application, g: $g$ a.i. ha ${ }^{-1}$, VCA: Vegetative cloning axes. 
DAHA, differences were statistically not significant. Plumular axes had similar behavior at both dates, though with lower proportions at 60 DAHA. All VCA treated showed less quantity of nodes with buds than the control. In general, the lower proportion of buds at 60 DAHA was related to a rise in the quantity of observed axes rather than a lack of development of any structure (data not shown).

In $E$. retusa, all treatments showed a proportion of buds close to or greater than 50\% (Fig. 3C-D). Interaction between dose and date had significant effect on the proportion of buds $(\mathrm{p}<0.0001)$. This interaction results from the differential behavior of the treated axes with the lowest dose. A contrast between doses at fixed dates indicated that at 30 DAHA, axes treated with $480 \mathrm{~g}$ a.i. ha ${ }^{-1}$ showed significantly higher proportion of buds compared to the rest of the treatments. In contrast, at 60 DAHA axes treated with $480 \mathrm{~g}$ a.i. ha ${ }^{-1}$ showed significantly less proportion than control axes. In the axes treated with $1200 \mathrm{~g}$ a.i. ha ${ }^{-1}$ buds proportion was similar to control on both dates.

\section{Viability classes}

Significant differences between bud viability classes at 30 and 60 DAHA $(\mathrm{p}=0.0064$ and $\mathrm{p}$ $=0.0003$, respectively) were observed using the Cochran-Mantel-Haenszel test. Commelina erecta showed a uniformly high active relative proportion of buds (70-100\%), even after herbicide application (Fig. 4A- B). Dormant buds comprised the second most frequent viability classes between the buds bank. Its proportion was very uneven between treatments and dates, being always much lower than in the active ones (maximum 20\%). Dead bud class was the least frequent. Statistically significant

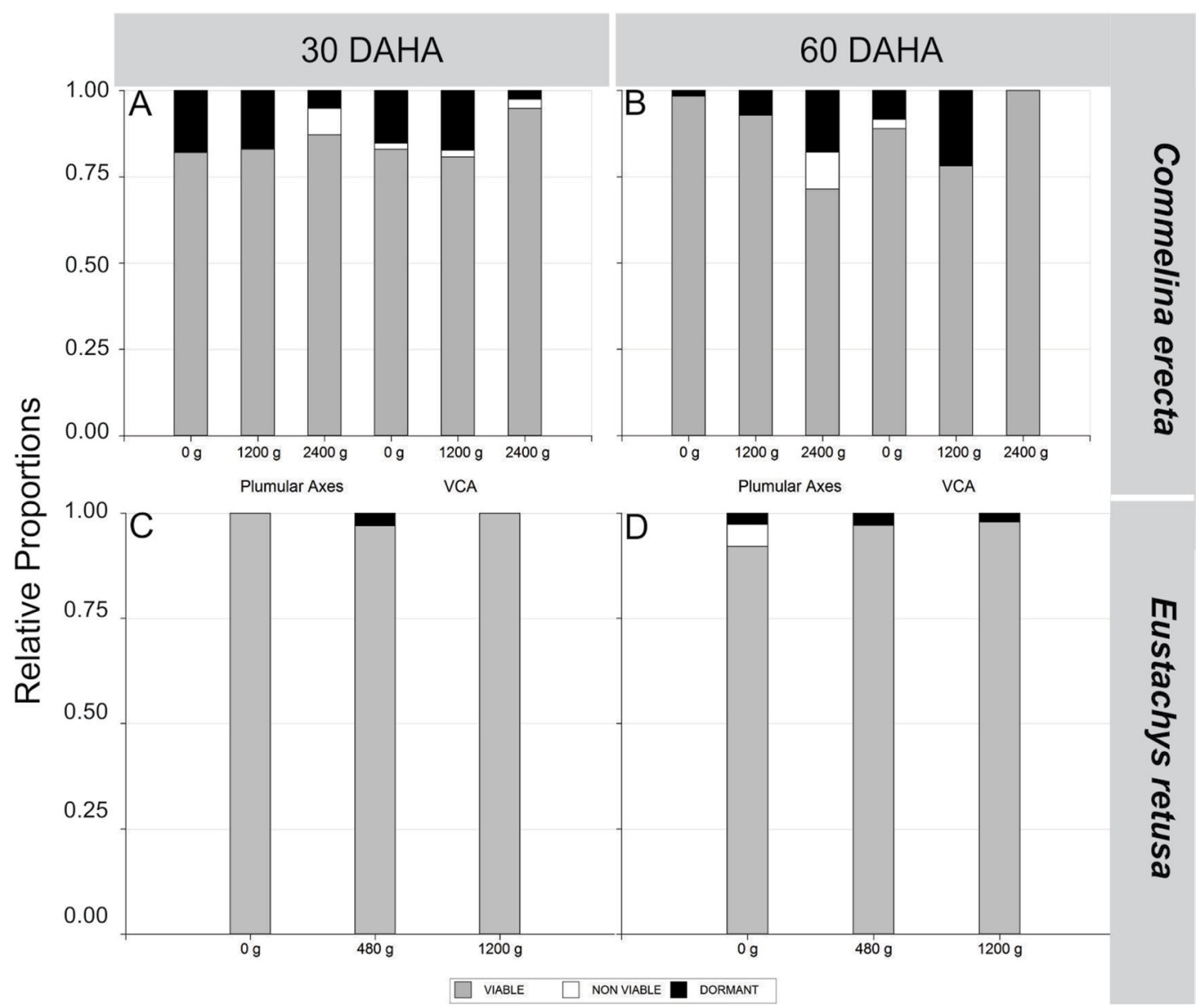

Fig. 4. Proportion of viability classes (active, dead or non-viable), in buds of both species. A: C. erecta at 30. B: C. erecta at 60 DAHA. C: E. retusa at 30 and D: E. retusa at 60 DAHA. Abbreviations: DAHA: days after the herbicide application. $\mathrm{g}: \mathrm{g}$ a.i. ha-1. 
interaction between the herbicide effect, origin and sampling date on the proportion of active buds was detected $(p=0.0484)$ with GLMM procedure. In this case, the response to herbicide dose for each origin differed between sampling date. However, the contrast between the different factors levels was nonsignificant, as in general, the percentages of active buds were always high in all the treatments on both dates. At 30 DAHA, axes of both origins showed the same trends. Treated axes with the higher dose showed the greatest percentage of active buds among all the treatments. At 60 DAHA, the plumular axes treated with the higher dose and the VCA treated with the lower dose showed the lowest percentage of active buds ( $71-78 \%$ respectively). The rest maintained between 90 and $100 \%$ of active buds.

The three viability classes were present in E. retusa, but not in all the examined axes. The association between viability classes and dose in both sampling dates was not significant. All treatments had a significantly higher proportion of active class, even after herbicide application (Fig. 4C- D). Dormant and dead viability classes were rarely observed. In all dates and treatments, a reserve of active buds was very high (more than 90\%). Generalized linear mixed-model procedure revealed that the proportion of active buds was not affected by any of the factors evaluated.

\section{Bud bank and Architectural traits}

In C. erecta, the probability of regeneration through the bud bank was constrained by the architecture, in control and treated conditions (Fig. 5A-D). The mid zone contributed the most to the bud bank in all treatments regardless the origin. The other zones also contributed, but their response depended on origin, herbicide dose and dates. In plumular axes

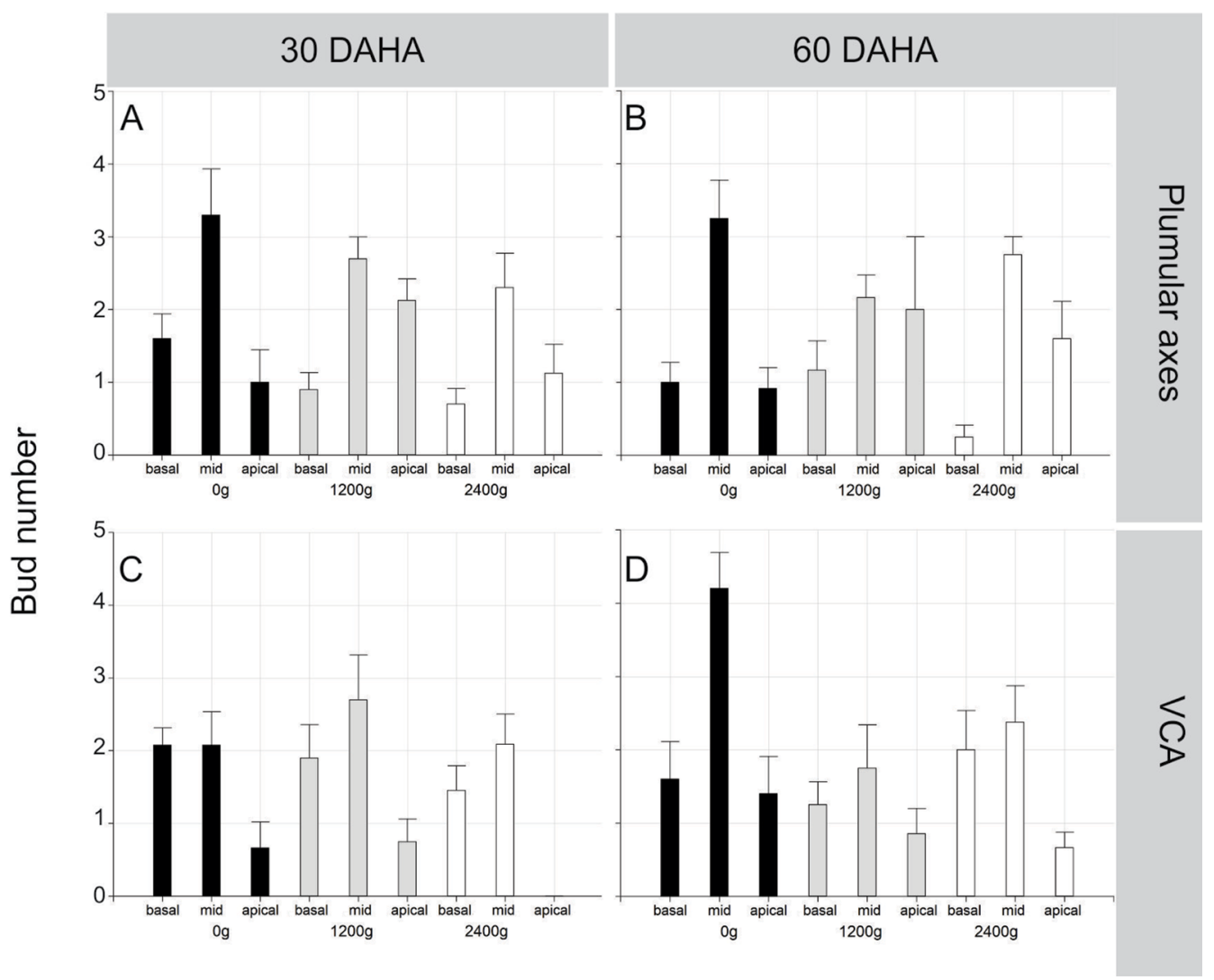

Fig. 5. Bud number along the structural areas (basal, mid and apical) in C. erecta. A: Plumular axes at 30 DAHA and B: at 60 DAHA. C: Vegetative cloning axes at 30 DAHA and D: at 60 DAHA. Abbreviations: DAHA: days after the herbicide application, g: $g$ a.i. ha ${ }^{-1}$, VCA: Vegetative cloning axes. Each color corresponds to herbicide dose. Values are means \pm standard errors. 


\section{E. S. Panigo et al. - Bud bank in herbaceous species}

there was a higher growth of axes in the basal zone than buds destined to the bank (rhizome systems increase), whereas in the apical zone the opposite occurred. On the contrary, in the VCA the basal zone contributed less to the bud bank compared to apical. As a consequence of this difference in response, there was a statistical interaction between origin and zone significant in both dates $(\mathrm{p}=0.013$ and $\mathrm{p}=0.05$, respectively). As for the herbicide doses, significant differences were only found at 30 DAHA $(p=0.032)$, where, on average, plants treated with the highest dose retained less buds in the bank than the rest. This response was also observed at 60 DAHA, although the differences were not statistically significant.

In E. retusa, the availability of buds for regrowth is also linked to architectural traits. Overall, the axes maintained a higher number of buds in the mid zone (Fig. 6A- B). The basal zone also retained the buds, but the probability to keep them tended to decrease over time. At 30 DAHA, the effect of dose and zone were not independent $(\mathrm{p}<$ 0.0001). In the basal zone, axes treated with 480 $\mathrm{g}$ a.i. $\mathrm{ha}^{-1}$ had significantly the highest number of buds. Consequently, these axes showed a different architectural form than the rest. In the mid zone, similar quantity of buds was observed in all doses. At 60 DAHA, there were only significant differences between zones $(\mathrm{p}<0.0001)$. The basal zone of the axes retained significantly less buds than the mid zone, which was more evident in axes treated with $480 \mathrm{~g}$ a.i. $\mathrm{ha}^{-1}$. This showed significantly less buds on average $(0.11)$ than control and axes treated with $1200 \mathrm{~g}$ a.i. ha ${ }^{-1}$ (2.93 and 2.94 respectively). In the mid zone the quantity of buds was similar in all the treatments and showed values similar to the previous sampling date (7-8 buds).
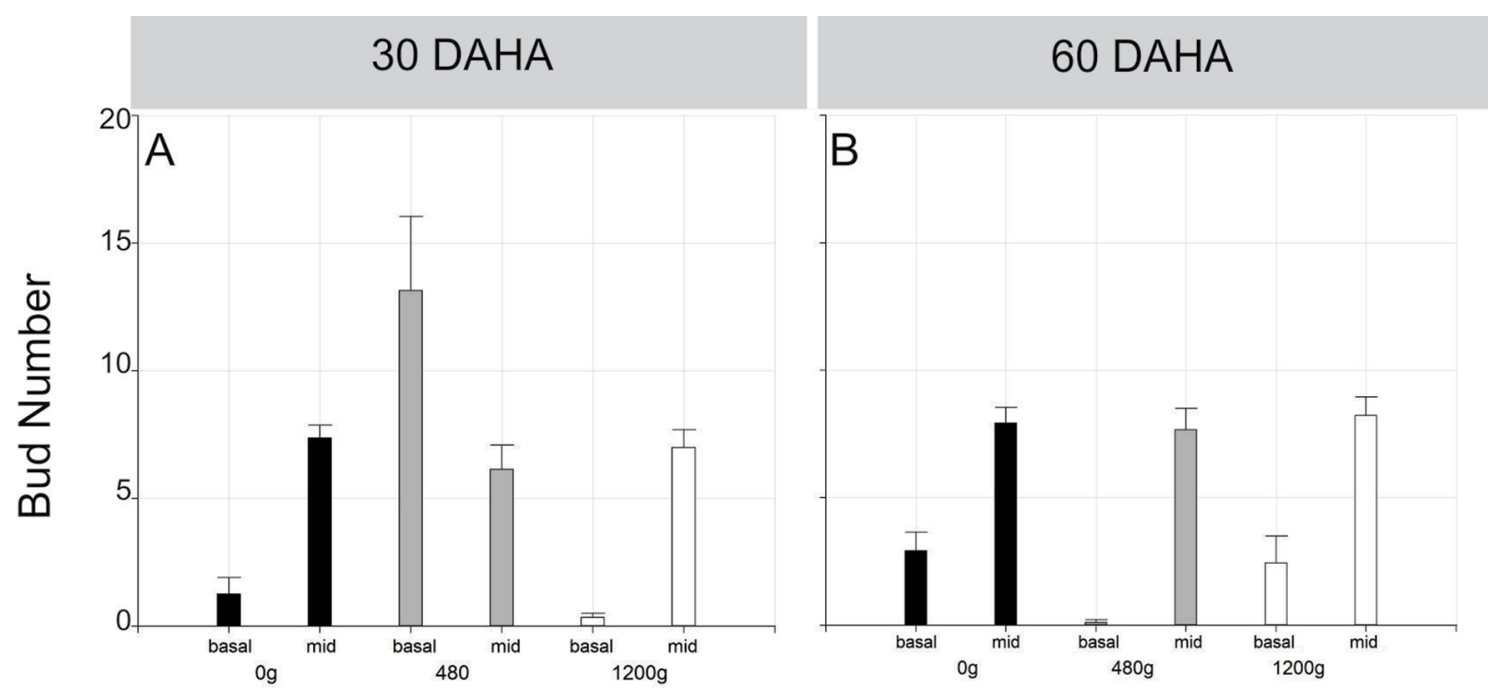

Fig. 6. Bud number along the structural areas (basal, mid and apical) in E. retusa. A: at 30 DAHA and B: at 60 DAHA. Abbreviations: DAHA: days after the herbicide application, $g: g$ a.i. ha ${ }^{-1}$. Each color corresponds to an herbicidal dose. Values are means \pm standard errors.

\section{Discussion}

One of the factors that contribute to the persistence of $C$. erecta and E. retusa in the no-tillage agroecosystems is the high potential of regeneration. Plants of both species showed a notorious reservoir of active buds which let them have a constant bud supply. The consistent bud supply would enable immediate regrowth response (Ott \& Hartnett, 2015) to herbicide application. In agroecosystems where the species suffer frequent disturbances (Nisensohn et al., 2011), plants with resprouting capacity represent a successful regeneration strategy (Klimešová \& 
Klimeš, 2003). Thus, a successful resprouting via the bud bank is key to population persistence (Ott \& Hartnett, 2015).

The herbicide did not have significant effects on the morphology, size and viability of the buds in both species. Though the effect of dose on proportion and number of buds always depended on the origin, the date and/or the considered zone, it might be related to the post-application resprouting responses. Size profiles by zone as well as the quantity of buds available in the axes were different in $C$. erecta when comparing the control plants to the treated plants on each date. All these results suggest that the fate of the bud (its presence of absence) and the zone that activates branching were different after herbicide application. Particularly, plumular axes treated with the lowest dose showed higher proportion of buds compared to control or the highest dose. The lowest proportion was observed in axes treated with the highest doses. Probably, axes treated with lower doses redirect their resources towards the rhizome, while those treated with the highest dose increase branching, which allows them to recover photosynthetically active foliar mass loss. This has also been observed in the VCAs and in E. retusa at 30 DAHA.

It is well known that the bud bank is strongly related to shoot architecture. The activation of originally inhibited buds in treated plants (Panigo et al., 2012, 2016), allowed weeds to survive to herbicide application by altering their growth pattern (Malpassi, 2005; Dellaferrera et al., 2015). The development of an average maximum of three extra branches per axis was frequent in the treated axes. This is essential to recover leaf mass after herbicide application (Panigo et al., 2012, 2016). These findings support the idea that although the complexity of the branching pattern is genetically determined, it is characterized for having plasticity at different environmental signals (ShimizuSato \& Mori, 2001), allowing the plants to adjust to spatial and temporal heterogeneity, thus minimizing stress exposure (Fourcaud et al., 2008).

Both species conserved active bud at around 50\% of nodes, and bud bank dynamics changed postapplication. However, the strategy of use of the buds bank was different between species and within $C$. erecta between origins (related to plants in different ontogenetic stages). Commelina erecta invested in a dual growth strategy or a different resourceallocation strategy according to origin. The VCA post-application allocated resources for branching development located mainly in the apical zone, as a quick way of increasing flower production (Panigo et al., 2012). In order to compensate this resource cost, a pool of buds without activation was maintained in the basal zone on the rhizome, of a considerable size and high viability. On the contrary, in plumular axes branch production in apical zone decreased, post- application and resources were directed towards the production of vegetative structures in basal zone, generating an increase of the rhizome system. These trade-offs between reproductive effort and growthrelated traits confer competitive ability and resistance to stressful environments (Bonser \& Aarssen, 2009), after the plant has reached a minimum vegetative size (Demetrio et al., 2014). On the other hand, E. retusa, retained more buds in the mid zone than in the basal zone, whereas it did not present buds in the apical zone. In the latter species, all axillary axes (tillers) are produced by iterative innovation from the plant base (Panigo et al., 2016). This explains the small quantity of basal buds of the bank observed at 30 DAHA in the treatment of $1200 \mathrm{~g}$ a.i. $\mathrm{ha}^{-1}$. A similar effect was observed at 60 DAHA in the lowest dose, implicating a delay in the effect, but basically meaning the same type of response.

Resprouting is a complex behavior and can vary with disturbance intensity, frequency, environmental conditions (Vesk \& Westoby, 2004), and also with plant size (Klimešová \& Martínková, 2004; Moreira et al., 2012). Even though the axes were all in the same phenological state, the different size and ontogenetic stage of the mother plant could be the reason why multiple trends were found. In order to initiate resprouting after disturbance, both meristems and stored reserves are required (Vesk \& Westoby, 2004; Moreira et al., 2012). Bud bank from rhizomes resulted in a factor which reinforces herbicide tolerance in these weeds. When the photosynthetic tissues are affected by disturbance, the availability of active buds and reserves are critical to recover the photosynthetic capacity (Busso et al., 1990), allowing a rapid development of vigorous shoots (Vesk \& Westoby, 2004). This is associated with the increment in the probability of surviving (Moreira et al., 2012), because it may help to replenish carbohydrates consumed during resprouting. As seen in other weeds, in conservation tillage systems, defoliation in early autumn is important to interrupt the loading of storage compounds into the rhizome systems 


\section{E. S. Panigo et al. - Bud bank in herbaceous species}

(Boström et al., 2013). This will facilitate further weed management in the spring, as the resprouting capacity will be more constrained.

\section{Conclusions}

We conclude that $C$. erecta and $E$. retusa have a large reservoir of active buds and present differences in the strategy of use, even between different origins in C. erecta. Because the bud bank might not be affected by the herbicide, interrupting compound storage in the rhizome and the reduction of the amount of active buds would be a key factor in order to achieve effective management of these weeds in no-tillage cropping systems.

The herbicide has low effect on the bud bank of $C$. erecta and E. retusa, and this reservoir of active buds plays a fundamental role in glyphosate tolerance strategy, functioning as a kind of life insurance, supporting their survival in environments often subjected to disturbances, like commercial agrosystems. Bud bank from rhizomes would be a factor reinforcing the high herbicide tolerance in these species as well as in other perennial weeds. Understanding the dynamic and mechanisms which alter the bud bank in perennial weeds is necessary in order to find more sustainable and addressed management strategies. Furthermore, as the resprouting capacity of studied species was similar at both dose of glyphosate; an increase of the dose of herbicide would not be a successful alternative. New research is needed to explore more holistic alternatives for the integrated control of these weeds species.

\section{Author Contributions}

ESP, IMD, ACV and MGP devised and designed the experiments. ESP performed the experiments. ESP, IMD and CAA performed statistical analyses. ESP, ACV and MGP wrote the manuscript.

\section{ACKNOWLEDgeMENTS}

Research was conducted in partial fulfilment of the requirement for a Doctorate at Universidad Nacional del Litoral. This work was supported by a CONICET scholarship, CAI+D UNL projects
(50020150100015LI), PIP CONICET projects (11220100100433) and PICT projects (20142678). We thank two anonymous reviewers for their critical reading and contribution to the improvement of the manuscript.

\section{BibLIOGRAPHY}

BOND, W. J. \& J. J. MIDGLEY. 2001. Ecology of sprouting in woody plants: the persistence niche. Trends Ecol. Evol. 16: 45-51. https://doi.org/10.1016/S0169-5347(00)02033-4

BONSER, S. P. \& L. W. AARSSEN. 2009. Interpreting reproductive allometry: Individual strategies of allocation explain size-dependent reproduction in plant populations. Perspect. Pl. Ecol. Evol. Syst. 1: 31-40. https://doi.org/10.1016/j.ppees.2008.10.003

BOSTRÖM, U., L. ANDERSSON, J. FORKMAN, I. HAKMAN, J. LIEW \& E. MAGNUSKI. 2013. Seasonal variation in sprouting capacity from intact rhizome systems of three perennial weeds. Weed Res. 53: 387-398. https://doi.org/10.1111/wre.12035

BURKART, A. 1969. Flora Ilustrada de Entre Ríos (Argentina). T. VI, Parte II. Colección Científica del INTA, Buenos Aires.

BUSSO, C. A., R. J. MUELLER \& J. H. RICHARDS. 1989. Effects of drought and defoliation on bud viability in two caespitose grasses. Ann. Bot. 63: 477-485. https:// doi.org/10.1093/oxfordjournals.aob.a087768

BUSSO, C. A., J. H. RICHARDS \& N. J. CHATTERTON. 1990. Nonstructural carbohydrates and spring regrowth of two cool-season grasses: Interaction of drought and clipping. J. Range. Managem. 43: 336343. https://doi.org/10.2307/3898928

BUSSO, C. A., C. GITTINS, G. F. BECKER \& L. GHERMANDI. 2011. Tiller hierarchy and defoliation frequency determine bud viability in the grass Poa ligularis. Ecol. Res. 26: 985-997. https://doi.org/10.1007/s11284-011-0857-9

CASAFE (Cámara de Sanidad Agropecuaria y Fertilizantes- República Argentina). 2017. Guía de productos fitosanitarios para la República Argentina. 18th ed. Buenos Aires, Argentina

DELLAFERRERA, I. M., N. J. GUARISE \& A. AMSLER. 2007. Relevamiento de malezas en cultivos de soja en sistema de siembra directa con glifosato del departamento San Justo (Provincia de Santa Fe). Revista FAVE -Sección Agrarias 5/6: 1525. https://doi.org/10.14409/fa.v5i1/2.1318 
DELlaFERRERA, I. M., E. S. PANIGO, F. GONZALEZ-TORRALBA, R. A. DE PRADO, P. J. CHRISTOFFOLETI \& M. G. PERRETA. 2015. Características estructurales y fisiológicas de Petunia axillaris relacionadas con su baja sensibilidad a glifosato. Revista Pl. Danin 33: 451-462. https://doi.org/10.1590/S0100-83582015000300008

DEMETRIO, G. R., F. F. COELHO \& M. E. BARBOSA. 2014. Body size and clonality consequences for sexual reproduction in a perennial herb of Brazilian rupestrian grasslands. Brazil. J. Biol 74: 744-749. https://doi.org/10.1590/bjb.2014.0070

DENG, Z., X. CHEN, Y. XIE, X. LI, Y. PAN \& F. LI. 2013. Effects of size and vertical distribution of buds on sprouting and plant growth of the clonal emergent macrophyte Miscanthus sacchariflorus (Poaceae). Aquatic Bot. 104: 121-126.

https://doi.org/10.1016/j.aquabot.2012.08.004

FOURCAUD, T., X. ZHANG, A. STOKES, H. LAMBERS \& C. KÖRNER. 2008. Plant Growth Modelling and Applications: The Increasing Importance of Plant Architecture in Growth Models. Ann. Bot. 101: 1053-1063. https://doi.org/10.1093/aob/mcn050

HARPER, J. L. 1977. Population biology of plants. $1^{\text {st }} \mathrm{ed}$. Academic Press, Lodon.

HENDRICKSON, J. R. \& D. D. BRISKE. 1997. Axillary bud banks of two semiarid perennial grasses: occurrence, longevity, and contribution to population persistence. Oecologia 110: 584-591. https://doi.org/10.1007/s004420050199

HOTHORN, T., F. BRETZ \& P. WESTFALL. 2008. Simultaneous inference in general parametric models. Biometr. J. 50: 346-363. https://doi.org/10.1002/bimj.200810425

KLIMEŠOVÁ, J. \& L. KLIMEŠ. 2003. Resprouting of herbs in disturbed habitats: is it adequately described by Bellingham-Sparrow's model? OIKOS 103: 225-229. https://doi.org/10.1034/j.1600-0706.2003.12725.x

KLIMEŠOVÁ, J. \& J. MARTÍNKOVÁ. 2004. Intermediate growth forms as a model for the study of plant clonality functioning: an example with root sprouters. Evol. Ecol. 18: 669-681. https://doi.org/10.1007/s10682-004-5149-1

KLIMEŠOVÁ, J. \& L. KLIMEŠ. 2007. Bud banks and their role in vegetative regeneration- A literature review and proposal for simple classification and assessment. Perspect. Pl. Ecol. Evol. Syst 8: 115129. https://doi.org/10.1016/j.ppees.2006.10.002
KLIMEŠOVÁ, J., V. LATZEL, F. DE BELLO \& J. M. VAN GROENENDAEL. 2008. Plant functional traits in studies of vegetation changes in response to grazing and mowing: towards a use of more specific traits. Preslia 80: 245-253.

MALPASSI, R. 2005. Efectos de la aplicación de quizalofop sobre la arquitectura y anatomía foliar de Eleusine indica. Agriscientia 22: 55-62. http://dx.doi.org/10.31047/1668.298x.v22.n2

MOREIRA, B., J. TORMO \& J. G. PAUSAS. 2012. To resprout or not to resprout: factors driving intraspecific variability in resprouting. OIKOS 121: 1577-1584. https://doi.org/10.1111/j.1600-0706.2011.20258.x

NISENSOHN, L., D. TUESCA, D. FACCINI, E. PURICELLI \& J. VITTA. 2011. Factores biológicos que determinan la competencia de Commelina erecta con otras malezas en sistemas de cultivo. Revista Pl. Danin 29: 97-106. https://doi.org/10.1590/S0100-83582011000100012

OTT, J. P. \& D. C. HARTNETT. 2015. Bud-bank and tiller dynamics of co-occurring C3 caespitose grasses in mixed-grass prairie. Amer. J. Bot. 102: 1462-1471. https://doi.org/10.3732/ajb.1500039

PANIGO, E. S., I. M. DELLAFERRERA, J. M. ACOSTA, A. G. BENDER, J. I. GARETTO \& M. G. PERRETA. 2012. Glyphosate-induced structural variations in Commelina erecta L. (Commelinaceae). Ecotoxicol. Environm. Safety 76: 135-142. https://doi.org/10.1016/j.ecoenv.2011.10.002

PANIGO, E. S., C. A. ALESSO, I. M. DELLAFERRERA, J. OLIVELLA \& M. G. PERRETA. 2016. Morphoarchitectural traits that allow the regeneration of Eustachys retusa (Poaceae) in systems with intensive glyphosate application. Revista Pl. Danin. 34: 709-719. https://doi.org/10.1590/s0100-83582016340400011

PANIGO, E. S. \& L. NISENSOHN. Commelina erecta L. En: FERNÁNDEZ; O. A., E. LEGUIZAMÓN, \& H. A. ACCIARESI (ed.) Malezas e Invasoras de la Argentina Tomo III, pp. 181-189. Ediuns, Bahía Blanca.

PURICELLI, E. \& D. FACCINI. 2005. Control de Eustachys retusa y Chloris barbata con glifosato. Soja en siembra directa. AAPRESID Septiembre: 112-123.

R DEVELOPMENT CORE TEAM. 2014. R: Alanguage and environment for statistical computing. R Foundation for Statistical Computing, Vienna, Austria, Disponible en: http://www.R-project. org/.] 


\section{E. S. Panigo et al. - Bud bank in herbaceous species}

RAINERO, H. 2004. Avances en el control de malezas con tolerancia al glifosato. Bol. INTA- EEA Manfredi 12: 5-12.

SHIMIZU-SATO, S. \& H. MORI. 2001. Control of outgrowth and dormancy in axillary buds. $P l$. Physiol 127: 1405-1413.

https://doi.org/10.1104/pp.010841

VESK, P. A. \& M. WESTOBY. 2004. Sprouting ability across diverse disturbances and vegetation types worldwide. J. Ecol. 92: 310-320. https://doi.org/10.1111/j.0022-0477.2004.00871.x VESK, P. A., D. I. WARTON \& M. WESTOBY. 2004. Sprouting by semi-arid plants: testing a dichotomy and predictive traits. OIKOS 107: 72-89. https://doi.org/10.1111/j.0030-1299.2004.13122.x

WALDIE, T., A. HAYWARD \& C. A. BEVERIDGE. 2010. Axillary bud outgrowth in herbaceous shoots: how do strigolactones fit into the picture? Pl. Molec. Biol. 73: 27-36.

https://doi.org/10.1007/s11103-010-9599-2 
